Int. J. Electrochem. Sci., 12 (2017) $1288-1305$

International Journal of

ELECTROCHEMICAL

SCIENCE

www.electrochemsci.org

\title{
Effect of Au Addition on Intermetallics Precipitation Tendency and Repassivation of $\mathrm{Al}_{88} \mathrm{Fe}_{5} \mathrm{Y}_{7}$ Glassy Alloy
}

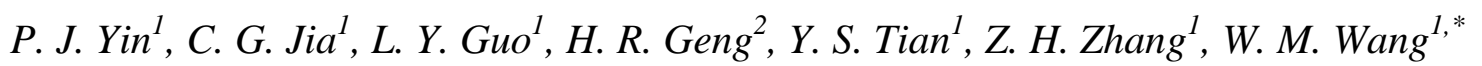 \\ ${ }^{1}$ Key Laboratory for Liquid-Solid Structural Evolution and Processing of Materials, Ministry of \\ Education, Shandong University, Jinan 250061, China \\ ${ }^{2}$ School of Materials Science and Engineering, University of Jinan, 106 Jiwei Road, Jinan, 250022, \\ China \\ *E-mail: weiminw@sdu.edu.cn
}

doi: $10.20964 / 2017.02 .15$

Received: 20 October 2016 / Accepted: 29 November 2016 / Published: 30 December 2016

The effects of $\mathrm{Au}$ addition and annealing on selective intermetallics precipitation and corrosion behaviors of the as-spun $\mathrm{Al}_{88-x} \mathrm{Fe}_{5} \mathrm{Y}_{7} \mathrm{Au}_{x}(x=0,0.5$ and 1) alloys have been investigated. When $\mathrm{Au}$ content $x=0$, the alloy has more preferentially precipitated AlY phase, the larger $\Delta E\left(=E_{\mathrm{p}}-E_{\mathrm{prot}}, E_{\mathrm{p}}\right.$ and $E_{\text {prot }}$ are piting and protective potentials) in Tafel curve, and the higher steepness $k_{\mathrm{s}}(=\mathrm{d} E / \mathrm{d} \log (I))$ on the reverse scan, suggesting that there exist some tunnels in the pit interiors and the repassivation can be hindered; whereas in case of $x=0.5$ and 1, the AlFe phase precipitates more easily, and the $\Delta E$ and $k_{\mathrm{S}}$ of the alloys are lower obviously. The repassivation and pitting transition of $\mathrm{Al}_{88-x} \mathrm{Fe}_{5} \mathrm{Y}_{7} \mathrm{Au}_{x}(x=$ $0,0.5$ and 1) glassy alloys are closely associated with the intermetallics precipitation tendency and fraction of amorphous phase.

Keywords: intermetallics selection; passivation; pitting transition; steepness; tunnel

\section{$\underline{\text { FULL TEXT }}$}

(C) 2017 The Authors. Published by ESG (www.electrochemsci.org). This article is an open access article distributed under the terms and conditions of the Creative Commons Attribution license (http://creativecommons.org/licenses/by/4.0/). 